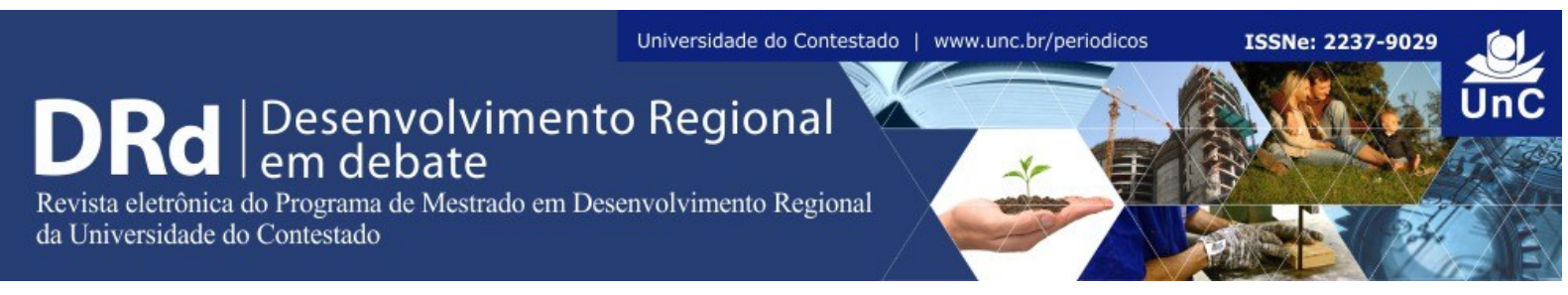

\title{
PERFIL LOCACIONAL DO EMPREGO FORMAL NAS MICRORREGIÕES DO RIO GRANDE DO SUL: 2004/2014
}

\author{
Paulo Eberhardt ${ }^{1}$ \\ Barbara Cardoso ${ }^{2}$
}

\begin{abstract}
RESUMO
O objetivo deste artigo é analisar a distribuição do emprego formal nas microrregiões do Rio Grande do Sul, nos anos 2004 e 2014, e quais atividades fazem parte da base exportadora. Para isso, utilizou-se o método do Quociente Locacional. Os resultados indicam que há microrregiões sendo fortalecidas pelo processo de encadeamento de varias atividades, enquanto outras estão em um processo de polarização, onde os municípios grandes estão determinando o padrão de especialização produtiva dos municípios menores Existem, ainda, algumas microrregiões em que o padrão de especialização é voltado para exportação. $\mathrm{O}$ estudo aponta que a especialização das microrregiões do RS está caminhando, cada vez mais, para a exportação de produtos secundários, com especialização tendendo ao setor terciário. Contudo, a agricultura mostrou ser um ramo de atividade que impulsiona as demais atividades devido ao encadeamento para trás e para frente, atraindo e concentrando o emprego na maioria das microrregiões.
\end{abstract}

Palavras-chave: Economia Gaúcha. Indicadores de análise regional. Economia regional.

\section{LOCATION PROFILE OF FORMAL EMPLOYMENT IN MICROREGIONS OF RIO GRANDE DO SUL STATE: 2004/2014}

\begin{abstract}
The aim of this paper is to analyze the formal employment distribution in the micro-regions of Rio Grande do Sul State, from 2004 to 2014, and what activities take part of the export-base. For this, we used the Location Quotient method. Results indicate that there are micro-regions being strengthened by chaining of various activities in the same micro-region, while other micro-regions are in the process of polarization, where the big cities are determining the pattern of productive specialization of smaller cities. There are also some micro-regions where the pattern of specialization is intended for export. The study shows that the specialization from the micro-regions of RS is increasingly moving towards the export of secondary products, with specialization tending to the tertiary sector. However, agriculture has shown to be a branch of activity that drives other activities due to backward and forward linkages, attracting and concentrating employment in most micro-regions.
\end{abstract}

Key-Words: Rio Grande do Sul State economy. Indicators of regional analysis. Regional economy.

\footnotetext{
${ }^{1}$ Mestre em Desenvolvimento Regional e Agronegócio pela Unioeste - Brasil. E-mail: pauloeberhardt@yahoo.com.br

2 Doutora em Desenvolvimento Regional e Agronegócio pela Unioeste - Brasil. E-mail: barbarafcardoso@gmail.com
}

DRd - Desenvolvimento Regional em debate (ISSNe 2237-9029)

v. 7, n. 1, p. 144-163, maio 2017. 


\section{INTRODUÇÃO}

O Rio Grande do Sul foi a quinta maior economia entre os estados brasileiros em 2015, com PIB de R\$ 319,8 bilhões, representando 6,2\% do PIB nacional, ficando atrás de São Paulo (R\$ 1,6 trilhões; 65,6\%), Rio de Janeiro (619,3 bilhões; 11,5\%), Minas Gerais (R\$ 458,0 bilhões; 9,2\%) e Paraná (R\$ 326,1 bilhões; 6,3\%), conforme o Instituto Brasileiro de Geografia e Estatística (IBGE, 2016).

De acordo com IBGE (2016), o Rio Grande do Sul tem 11,2 milhões de habitantes, cerca de 5,5\% da população brasileira. Os empregados, em 2013, estavam distribuídos da seguinte forma: 867 mil no setor primário, 1,8 milhão no setor secundário e 3,5 milhões no setor terciário. Porém, segundo o Ministério do Trabalho e Emprego/Relação Anual de Informações Sociais (MTE/RAIS, 2016), que considera apenas emprego formal, o número de trabalhadores se reduz em todos os setores, permanecendo 82,6 mil no setor primário, 784,8 mil no setor secundário e 2,2 milhões no setor terciário.

As principais atividades que movem a economia sul rio-grandense são a agropecuária e a indústria de transformação, embora o setor de serviços possua significante participação no valor agregado do estado (cerca de 65\%). Cabe ressaltar que o setor primário da economia do Rio Grande do Sul representou em 2013, 10,1\% do valor agregado bruto do estado, enquanto o setor secundário e o terciário representaram $24,3 \%$ e $65,6 \%$, respectivamente. Salienta-se, ainda, que a economia do estado possui forte relação com o comércio internacional, fazendo com que a economia sul rio-grandense oscile de acordo com a evolução da economia brasileira e com a dinâmica das exportações (ATLAS SOCIOECONÔMICO DO RIO GRANDE DO SUL, 2016).

Isto posto, este trabalho possui o objetivo de analisar a distribuição do emprego formal nas microrregiões do Rio Grande do Sul, nos anos 2004 e 2014, e quais atividades fazem parte da base exportadora.

Para tanto, este artigo está dividido em quatro seções, das quais a primeira é esta breve introdução. Na segunda seção são abordados os principais aspectos teóricos e metodológicos que nortearam esta pesquisa. Os resultados, divididos por mesorregiões para o melhor entendimento, são apresentados na terceira seção. E, por fim, na quarta seção, expõem-se as considerações finais.

\section{ASPECTOS TEÓRICOS}

Para analisar a distribuição do emprego nas microrregiões gaúchas, é importante se recorrer a algumas das correntes teóricas clássicas que tratam do desenvolvimento regional, que, segundo Monastério e Cavalcante (2011) são: a) a teoria dos pólos de François Perroux; b) a base econômica de Douglass North; c) os efeitos para frente e para trás de Albert Hirschman e; d) a causação circular e acumulativa de Gunnar Myrdal. 
Para Perroux (1977), o crescimento e desenvolvimento das regiões são heterogêneos, tanto no tempo, quanto no espaço. As regiões e suas aglomerações não se desenvolvem na mesma intensidade. A aglomeração mais significativa detém concentração econômica, política e populacional, e, assim, exercem influência sobre as demais regiões próximas, caracterizando o pólo motrizador.

Para uma região se tornar um pólo de crescimento, esta deve possuir o que Perroux denominou de empresa ou unidade motriz. A empresa ou conjunto de empresas será o "motor" da economia local, gerando renda e emprego. O autor também introduziu o termo "pólo de desenvolvimento", cuja definição é mais complexa. O conceito de desenvolvimento é motivo de intenso debate, pois no âmbito do desenvolvimento, os fatores usados para sua explicação extrapolam os fatores econômicos (PERROUX, 1977).

Lima e Simões (2009) afirmam que Perroux foi o primeiro a adotar a noção de espaço econômico enquanto conceito matemático de espaço abstrato para a análise de fenômenos econômicos. Considerando esta definição de espaço econômico, Perroux (1977, p. 164) afirma que "[...] o crescimento não surge em toda parte ao mesmo tempo; manifesta-se com intensidades variáveis, em pontos ou pólos de crescimento; propaga-se, segundo vias diferentes e com efeitos finais variáveis, no conjunto da economia".

O crescimento, na visão de Perroux, estaria ligado à existência de uma indústria motriz que permitiria o surgimento de outras indústrias e encadearia a propagação do crescimento econômico. Lima e Simões (2009, p. 8) afirmam que,

O aparecimento de uma indústria nova (ou grupo de indústrias) ou o crescimento de uma indústria existente possui efeitos de propagação na economia através de preços, fluxos e antecipações. Assim, para analisar essa modalidade de crescimento é preciso considerar o papel desempenhado pela indústria motriz, pelo complexo de indústrias e pelo crescimento dos pólos de desenvolvimento.

Contudo, o crescimento de um pólo de desenvolvimento pode não acarretar no desenvolvimento da região, uma vez que a implantação deste pólo pode provocar desequilíbrios econômicos e sociais ao redistribuir salários e rendimentos sem, necessariamente, aumentar a produção de bens de consumo. Além disso, a transferência de mão-de-obra para outras atividades pode não resultar em um novo enquadramento social (LIMA; SIMỖES, 2009).

Cabe ressaltar que em todos os países de economia capitalista há regiões que cresceram mais do que outras, e confirmam a teoria dos pólos de François Perroux (1977). No Brasil, por exemplo, o estado de São Paulo possui a maior concentração econômica e populacional do país, o que o torna o maior pólo brasileiro. Na Bahia, a capital Salvador se tornou o centro de influência não só para os municípios vizinhos, mas para todo o Estado. No Oeste baiano, um dos "motores" da economia regional é o agronegócio, que tem o impulso que muitos municípios necessitam para se desenvolver economicamente e, passar de um modelo apenas monoespecializado para poliespecializado diversificado (EBERHARDT, 2014). Essa dependência que os municípios do Oeste baiano têm no agronegócio reforça uma das teorias clássicas que explicam o crescimento das regiões, que é a teoria da base de econômica de Douglass North (1955). De acordo com esta teoria, a taxa de crescimento de uma região está limitada à taxa de crescimento de suas atividades motoras, denominadas por North (1955) de atividades básicas ou de base. As atividades básicas se constituem naquelas 
em que produzem bens e serviços na região e também atendem o mercado inter-regional. Quanto maior for a demanda das outras regiões por bens e serviços, maior será o crescimento da região produtora. Com o crescimento das atividades básicas, estas demandarão maiores quantidades de insumos fornecidos pelas indústrias da região, denominadas de atividades nãobásicas.

A teoria da base econômica de North (1955) surgiu em resposta aos estágios de desenvolvimento apresentados pelas teorias da localização e do crescimento regional para explicar a dinâmica do desenvolvimento de uma economia. De acordo com estas teorias, uma economia se desenvolveria passando pelos seguintes estágios: a) economia de subsistência, autossuficiente e agrícola; b) desenvolvimento do comércio e da especialização local; c) desenvolvimento do comércio inter-regional e diversificação das atividades agropecuárias; d) industrialização; e e) especialização em atividades terciárias para exportação. North percebeu que nem todas as economias passam por estes estágios. Ao analisar a economia dos Estados Unidos e do Pacífico Noroeste, ele identificou falta de correspondência do desenvolvimento destas economias com os estágios de desenvolvimento supracitados, e que estas economias se desenvolveram mais pela produção de produtos exportáveis.

Dessa forma, North desenvolveu o conceito de base de exportação para designar os produtos exportáveis de uma região. Segundo Lima e Simões (2009, p. 22-23),

O desenvolvimento de um artigo de exportação refletia uma vantagem comparativa nos custos relativos da produção, incluindo custos de transferência e, à medida que as regiões cresciam em torno desta base eram geradas economias externas, que, por sua vez, estimulavam a competitividade dos artigos de exportação. A base de exportação desempenhava assim papel fundamental na conformação da economia de uma região e em seus níveis de renda absoluta e per capita e, consequentemente, na determinação da quantidade de atividades locais, secundárias e terciárias, que se desenvolveriam, bem como sobre a dinâmica da indústria subsidiária, a distribuição da população, o padrão de urbanização, as características da força de trabalho, as atitudes sociais e políticas e o crescimento dos centros nodais, de tal forma que seu crescimento estava intimamente vinculado ao sucesso de suas exportações.

Os produtos exportáveis, sejam eles do setor primário, secundário ou terciário, são as atividades básicas, que criam condições para que as atividades não básicas se desenvolvam. North $(1955$; 1977) afirma que as atividades relacionadas à agropecuária são, por natureza, atividades básicas, pois, têm funções ligadas ao fornecimento de matéria-prima para outras atividades, gerando, assim, encadeamentos naturais entre as atividades. Além disso, conforme Bacha (2004), a agropecuária também possui as funções de liberar mão-de-obra para o crescimento e diversificação das atividades econômicas, fornecer divisas para a compra de insumos e bens de capital necessários ao desenvolvimento de todas as atividades econômicas, fornecer alimentos para a população e capital para a expansão dos demais setores, e constituise em mercado consumidor para os produtos não agrícolas. Tais funções reforçam a natureza dos encadeamentos promovidos pela agropecuária.

De fato, a produção de commodities agropecuárias também gera encadeamentos produtivos a montante e a jusante na cadeia agroalimentar. As atividades primárias produzem matérias-primas para transformação nas agroindústrias e, também, produzem encadeamentos a montante, nas indústrias de fertilizantes, sementes, adubos, herbicidas, fungicidas e combustível. Essa ligação entre os efeitos das atividades básicas sobre as não-básicas foi 
denominada por Hirschmann (1958) de efeitos encadeadores, havendo os efeitos para frente (forward linkages) e os efeitos para trás (backward linkages).

Para Hirshmann (1958), as decisões de investimento também são importantes para a determinação destes efeitos, pois os investimentos nos serviços básicos, tais como saúde, educação, transporte, saneamento, energia, entre outros, são fundamentais para o funcionamento dos demais serviços, tanto no setor primário, quanto no secundário e no terciário.

Tais investimentos têm papel fundamental no desenvolvimento industrial, principalmente na industrialização voltada para a produção de bens intermediários ou de consumo final, e podem estimular os encadeamentos, particularmente, os efeitos para trás. De acordo com Hirschmann (1958, p. 112), “[...] os efeitos para trás são importantes não apenas da produção secundária para a primária, mas também da terciária para a secundária e primária". Esses efeitos para frente (forward linkages) e para trás (backward linkages) são importantes na formação de cadeias produtivas, nas quais uma atividade de produção de bens e serviços terá capacidade de geração de renda e emprego em outras atividades.O aumento da renda e a geração de empregos fazem com que a região se torne alvo de pessoas de outras regiões, que buscam melhores condições de vida. Esse aumento da renda e de investimentos acarreta em aumento também da poupança, que acaba por gerar uma nova onda de investimentos. Esses efeitos criam um círculo virtuoso da riqueza, no qual o crescimento econômico acaba gerando mais crescimento. Esse efeito foi denominado por Gunnar Myrdal (1957) de "efeito difusão" (spread effects), que surge quando o círculo virtuoso da riqueza transborda o território da região e cria um impulso para as regiões mais atrasadas. Já os "efeitos de retroação" (backwash effects) são os efeitos negativos que as regiões menos desenvolvidas têm ao se localizarem próximas às regiões mais desenvolvidas. Esses efeitos podem ser do poder de atração que a região mais desenvolvida exerce sobre as demais, através da concentração industrial e populacional (MONASTÉRIO; CAVALCANTE, 2011).

Lima e Simões (2009) complementam argumentando que o processo de causação circular, isto é, o círculo vicioso da riqueza, é de grande importância para entender as relações sociais e, também, a perda de uma indústria em uma determinada região, por exemplo. Neste caso, a perda de uma indústria poderia acarretar em desemprego e redução da renda e da demanda local.

Para Furtado (2000), as transformações apontadas por Perroux (1977), Hirschmann (1958) e Myrdal (1957) se dão em um processo histórico, na qual a introdução de inovações produz melhorias nos processos de transformação e produção, aumentando, assim, o número de empregos criados, gerando acréscimos na renda, acumulação de capital e aumento nos investimentos em capital fixo e humano.

\section{ASPECTOS METODOLÓGICOS}

Para se verificar qual a composição do emprego formal das microrregiões do Rio Grande do Sul foram utilizados alguns indicadores do arcabouço metodológico da análise regional, mais especificamente o Quociente Locacional (QL) e o multiplicador de emprego. A 
vantagem em se utilizar esse tipo de indicador está na simplicidade matemática e estatística, assim como na facilidade de interpretar os resultados. Esses indicadores são baseados em Haddad (1989) e Piffer (1997; 1999).

A variável escolhida para essa pesquisa foi emprego formal, encontrada na base de dados da Relação Anual de Informações Sociais (RAIS), do Ministério do Trabalho e Emprego (MTE). A variável emprego é um indicador importante nos estudos sobre economia regional, pois permite identificar e analisar o perfil da região. As regiões dinâmicas possuem uma estrutura produtiva capaz de criar emprego e renda.

O Quociente Locacional mostra como estão dispersos os empregos formais, tendo como base setores da atividade econômica e uma região de referência, que nessa pesquisa foi o Rio Grande do Sul. Portanto, foi calculado o QL para as 35 microrregiões do Rio Grande do Sul e 25 ramos de atividade, para 2004 e 2014. As microrregiões do Rio Grande do Sul são mostradas na Figura 1.

Figura 1 - Microrregiões pertencentes ao estado do Rio Grande do Sul

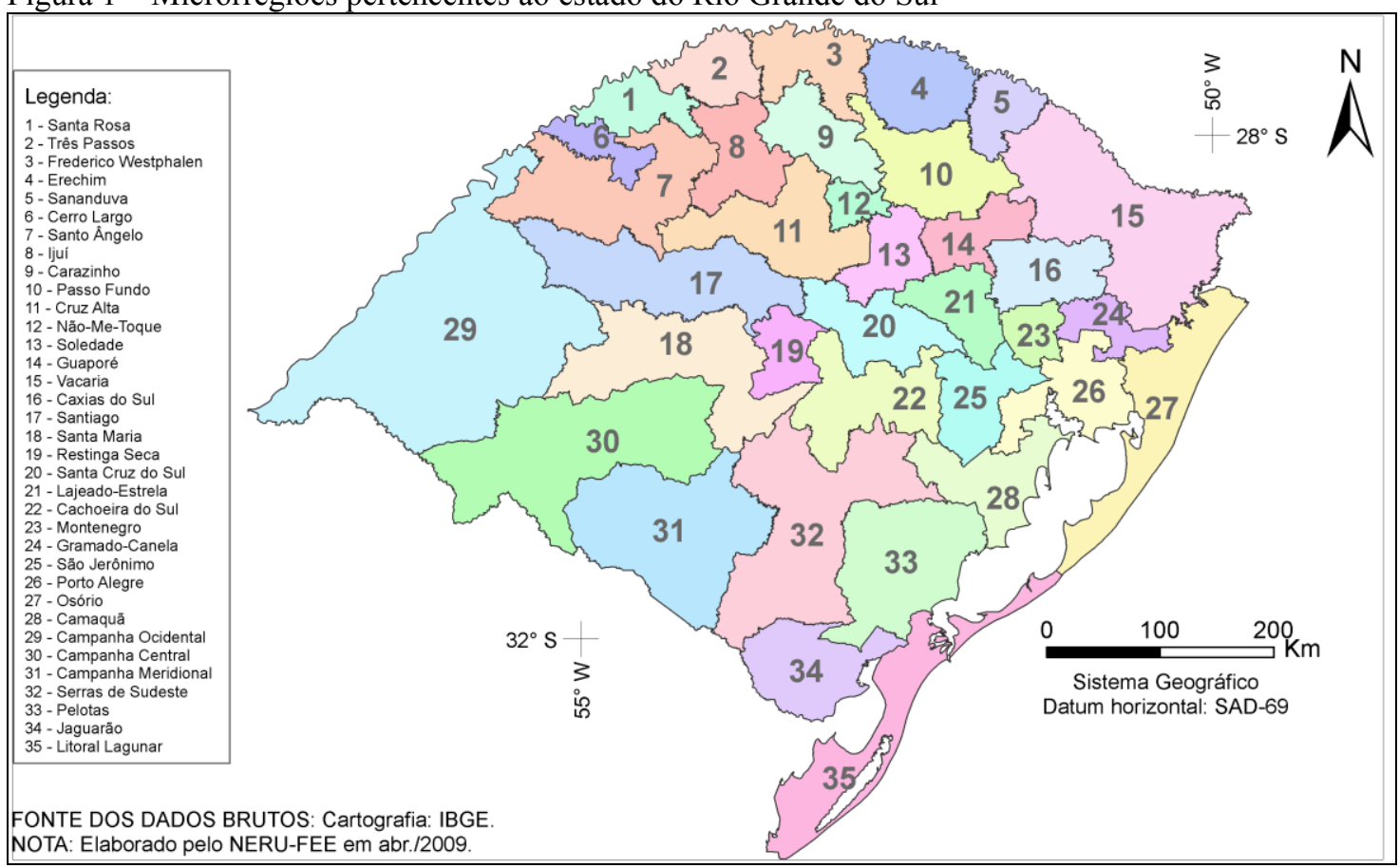

Fonte: Núcleo de Estudos Regionais e Urbanos/Fundação de Economia e Estatística (NERU/FEE, 2009).

O QL mostra a concentração do maior número de empregos formais em relação à região de referência. Essa concentração pode sugerir uma especialização da região em determinado ramo de atividade.

Para o cálculo do QL, organizaram-se as informações em uma matriz que relaciona a distribuição setorial-espacial de uma variável-base. Definiu-se a matriz da seguinte forma: 


$$
\mathrm{QL}_{\mathrm{ij}}=\frac{\mathrm{C}_{\mathrm{ij}} / \sum_{\mathrm{j}} \mathrm{C}_{\mathrm{ij}}}{\sum_{\mathrm{i}} \mathrm{C}_{\mathrm{ij}} / \sum_{\mathrm{i}} \sum_{\mathrm{j}} \mathrm{C}_{\mathrm{ij}}}
$$

Em que:

$\mathrm{C}_{\mathrm{ij}}=$ emprego formal no ramo de atividade $i$ da microrregião $j$;

$\sum_{\mathrm{j}} \mathrm{C}_{\mathrm{ij}}=$ emprego formal no ramo de atividade $i$ de todas as microrregiões;

$\sum_{\mathrm{i}} \mathrm{C}_{\mathrm{ij}}=$ emprego formal em todos os ramos de atividade da microrregião $j$;

$\sum_{\mathrm{i}} \sum_{\mathrm{j}} \mathrm{C}_{\mathrm{ij}}=$ emprego formal em todos os ramos de atividade $\mathrm{e}$ de todas as microrregiões.

Os valores de QL que assumirem valores superiores à unidade são considerados importantes no contexto regional por possuírem uma concentração relevante de emprego formal, e, usualmente, considerados como pertencentes à base econômica da região.

Porém, conforme Monastério (2011), a interpretação do QL requer cuidados. Com QL superior à unidade, pode-se sugerir uma maior especialização da região, levando à exportação. Contudo, se o setor em questão utiliza-se de mão-de-obra intensiva, seu QL pode ser ilusório, não gerando exportações.

Com a evolução do QL de 2004 a 2014 é possível identificar qual a composição do emprego formal entre os ramos de atividade e estimar quais as microrregiões gaúchas que possuem uma base econômica mais fortalecida.

\section{RESULTADOS E DISCUSSÕES}

O Rio Grande do Sul é composto por sete mesorregiões, a saber: Sudeste, Noroeste, Nordeste, Metropolitana de Porto Alegre, Centro Oriental, Centro Ocidental e Sudoeste.

A mesorregião Sudeste Rio-Grandense possui cinco microrregiões: Jaguarão, Litoral Lagunar, Pelotas, e Serras de Sudeste. A estimação do QL para as microrregiões pertencentes a esta mesorregião está exposta na Tabela 1. 
Tabela 1 - Quociente Locacional das microrregiões pertencentes à mesorregião Sudeste Rio-Grandense.

\begin{tabular}{|c|c|c|c|c|c|c|c|c|}
\hline \multirow{2}{*}{$\begin{array}{c}\text { Microrregião/ } \\
\text { Ramo de atividade }\end{array}$} & \multicolumn{2}{|c|}{ Jaguarão } & \multicolumn{2}{|c|}{ Litoral Lagunar } & \multicolumn{2}{|c|}{ Pelotas } & \multicolumn{2}{|c|}{ Serras de Sudeste } \\
\hline & 2004 & 2014 & 2004 & 2014 & 2004 & 2014 & 2004 & 2014 \\
\hline Extrativa Mineral & 0,328 & 0,165 & 0,417 & 1,457 & 1,392 & 0,651 & 20,404 & 28,755 \\
\hline Prod. Mineral Não Metálico & 0,346 & 0,000 & 0,044 & 0,134 & 1,665 & 1,187 & 5,969 & 6,678 \\
\hline Indústria Metalúrgica & 0,185 & 0,022 & 0,088 & 0,299 & 0,149 & 0,203 & 0,062 & 0,171 \\
\hline Indústria Mecânica & 0,000 & 0,030 & 0,097 & 0,268 & 0,390 & 0,265 & 0,063 & 0,007 \\
\hline Elétrico e Comunic & 0,000 & 0,000 & 0,011 & 0,035 & 0,236 & 0,191 & 0,000 & 0,018 \\
\hline Material de Transporte & 0,000 & 0,000 & 0,027 & 6,329 & 0,131 & 0,133 & 0,042 & 0,000 \\
\hline Madeira e Mobiliário & 0,126 & 0,047 & 0,552 & 0,321 & 0,129 & 0,193 & 2,178 & 1,793 \\
\hline Papel e Gráf & 0,060 & 0,115 & 0,186 & 0,157 & 0,523 & 0,478 & 0,099 & 0,139 \\
\hline Borracha, Fumo, Couros & 0,069 & 0,000 & 0,045 & 0,178 & 0,598 & 0,561 & 0,059 & 0,234 \\
\hline Indústria Química & 0,000 & 0,052 & 0,787 & 2,163 & 0,538 & 0,078 & 0,032 & 0,019 \\
\hline Indústria Têxtil & 0,000 & 0,055 & 0,089 & 0,125 & 0,279 & 0,233 & 0,385 & 0,902 \\
\hline Indústria Calçados & 0,000 & 0,000 & 0,005 & 0,000 & 0,010 & 0,006 & 0,157 & 0,002 \\
\hline Alimentos e Bebidas & 0,315 & 0,196 & 1,776 & 0,787 & 2,161 & 1,572 & 0,351 & 0,390 \\
\hline Serviço Utilidade Pública & 1,295 & 1,016 & 1,324 & 1,208 & 0,609 & 1,964 & 3,742 & 4,259 \\
\hline Construção Civil & 0,074 & 0,375 & 0,605 & 0,722 & 0,862 & 1,099 & 0,659 & 0,220 \\
\hline Comércio Varejista & 1,384 & 1,481 & 1,260 & 1,148 & 1,345 & 1,323 & 0,996 & 1,068 \\
\hline Comércio Atacadista & 0,879 & 0,249 & 0,715 & 0,329 & 0,879 & 0,825 & 1,324 & 0,879 \\
\hline Instituição Financeira & 0,766 & 0,841 & 0,659 & 0,776 & 0,863 & 0,944 & 0,607 & 0,793 \\
\hline Adm Técnica Profissional & 0,298 & 0,717 & 1,244 & 0,598 & 0,866 & 0,880 & 1,519 & 0,404 \\
\hline Transporte e Comunicações & 0,507 & 0,620 & 2,155 & 1,857 & 1,052 & 1,034 & 0,745 & 0,620 \\
\hline Aloj Comunic & 0,705 & 0,946 & 1,474 & 1,087 & 1,130 & 1,104 & 0,420 & 0,459 \\
\hline Médicos Odontológicos Vet & 0,979 & 0,720 & 0,837 & 0,892 & 1,417 & 1,438 & 0,718 & 0,619 \\
\hline Ensino & 0,214 & 0,184 & 0,546 & 1,154 & 1,381 & 2,024 & 0,213 & 0,152 \\
\hline Administração Pública & 1,253 & 1,446 & 1,061 & 0,810 & 1,172 & 0,931 & 1,300 & 1,748 \\
\hline Agricultura & 10,064 & 9,417 & 2,374 & 1,986 & 1,324 & 1,102 & 3,995 & 4,903 \\
\hline
\end{tabular}

Fonte: Resultados da pesquisa.

A microrregião de Jaguarão possui três ramos de atividade com QL superior a unidade: Serviços de Utilidade Pública, Comércio Varejista, e Administração Pública, em ambos os anos. A explicação do aparecimento de Serviços de Utilidade Pública e Administração Pública se dá pela correlação existente entre esses ramos de atividade, já que os serviços de utilidade pública, sendo caracterizados como bens públicos, são ofertados em boa parte pela administração pública, ou seja, quanto mais serviços de utilidade pública forem ofertados, maior tende a ser a representação da administração pública.

Na microrregião Litoral Lagunar, apesar de possuir um segmento no ramo de madeira, não possui QL expressivo nessa atividade; diferentemente das atividades ligadas à agricultura, que possuem empregos ligados à preservação e fabricação de pescado. $\mathrm{O}$ mesmo ocorre na microrregião de Pelotas, em que o QL para o setor primário è maior do que a unidade, dado suas atividades ligadas à fabricação de conservas de frutas e fabricação de produtos de arroz. No que concerne ao comércio varejista, a explicação do QL superior a unidade se deve às atividades ligadas a produtos de padaria e laticínios.

$\mathrm{Na}$ microrregião de Serras de Sudeste, as atividades ligadas ao desdobramento de madeira oferecem suporte para explicar o motivo pelo qual o ramo de atividade de madeira e mobiliário possuem QL acima de 1. Nas demais atividades, não houve variação significativa do QL de 2004 para 2014, com exceção da atividade de extração mineral, que tem QL bem

DRd - Desenvolvimento Regional em debate (ISSNe 2237-9029) 
acima de 1. Porém, valores muito acima da unidade não representam, necessariamente, especialização dessa atividade pela microrregião. Dado que o QL não leva em consideração apenas os valores da microrregião, mas também os dados de todas as microrregiões, o aumento ou mesmo o valor muito acima de 1 do QL pode simplesmente indicar que houve queda no número de empregos formais nessa atividade nas demais microrregiões e, não necessariamente, um aumento do emprego na microrregião analisada.

A mesorregião Noroeste possui 13 microrregiões e, por isso, foi dividida em duas nesta pesquisa: Noroeste Rio-Grandense (A) e Noroeste Rio-Grandense (B). A primeira é composta por seis microrregiões, a saber: Santa Rosa, Três Passos, Frederico Westphalen, Erechim, Sananduva e Cerro Largo. O QL para estas microrregiões encontra-se na Tabela 2.

Na microrregião de Santa Rosa, o QL acima de 1 na indústria mecânica é passível de explicação pela existência de fabricação de máquinas e equipamentos para a agricultura e também a presença de fabricação de móveis, da mesma forma que o observado em Serras de Sudeste, na mesorregião Sudeste. A indústria mecânica também é expressiva em Três Passos. Embora tenha havido queda no QL, ainda assim este foi significativo em 2014, por haver fabricação de máquinas para agricultura. Este fato é relevante, pois o QL do setor primário não é significativo em Três Passos, o que significa que a produção de maquinário agrícola pode ser voltada para exportação, o que contribui para a base econômica dos municípios pertencentes à microrregião de Três Passos.

Tabela 2 - Quociente Locacional das microrregiões pertencentes à mesorregião Noroeste Rio-Grandense (A).

\begin{tabular}{|c|c|c|c|c|c|c|c|c|c|c|c|c|}
\hline \multirow[t]{2}{*}{$\begin{array}{c}\text { Microrregião/ } \\
\text { Ramo de atividade }\end{array}$} & \multicolumn{2}{|c|}{ Santa Rosa } & \multicolumn{2}{|c|}{ Três Passos } & \multicolumn{2}{|c|}{$\begin{array}{c}\text { Frederico } \\
\text { Westphalen }\end{array}$} & \multicolumn{2}{|c|}{ Erechim } & \multicolumn{2}{|c|}{ Sananduva } & \multicolumn{2}{|c|}{ Cerro Largo } \\
\hline & 2004 & 2014 & 2004 & 2014 & 2004 & 2014 & 2004 & 2014 & 2004 & 2014 & 2004 & 2014 \\
\hline Extrativa Mineral & 0,764 & 0,033 & 0,586 & 0,653 & 0,680 & 0,565 & 0,333 & 0,242 & 0,079 & 1,040 & 1,532 & 1,020 \\
\hline Prod. Mineral Não Metálico & 1,583 & 1,373 & 0,550 & 1,134 & 2,326 & 2,376 & 0,956 & 1,175 & 1,286 & 1,568 & 0,996 & 1,380 \\
\hline Indústria Metalúrgica & 0,981 & 0,854 & 0,291 & 0,619 & 0,591 & 0,474 & 0,678 & 1,024 & 0,223 & 0,562 & 0,953 & 0,403 \\
\hline Indústria Mecânica & 4,703 & 3,461 & 5,553 & 2,569 & 0,031 & 0,121 & 1,643 & 1,485 & 0,022 & 0,232 & 1,287 & 1,141 \\
\hline Elétrico e Comunic & 0,112 & 0,220 & 0,000 & 0,012 & 0,203 & 0,369 & 0,362 & 0,277 & 0,026 & 0,031 & 0,000 & 0,077 \\
\hline Material de Transporte & 0,166 & 0,148 & 0,003 & 0,004 & 0,004 & 0,065 & 3,063 & 2,434 & 0,011 & 0,066 & 0,061 & 0,189 \\
\hline Madeira e Mobiliário & 1,241 & 1,312 & 1,442 & 1,383 & 1,334 & 0,798 & 1,183 & 1,273 & 1,974 & 1,392 & 0,609 & 0,970 \\
\hline Papel e Gráf & 0,891 & 0,591 & 0,331 & 1,369 & 0,375 & 0,475 & 2,307 & 1,957 & 0,348 & 0,360 & 0,268 & 0,492 \\
\hline Borracha, Fumo, Couros & 0,247 & 0,277 & 0,034 & 0,290 & 0,663 & 0,528 & 0,634 & 0,812 & 0,051 & 0,033 & 0,353 & 0,340 \\
\hline Indústria Química & 0,218 & 0,254 & 0,193 & 0,251 & 0,524 & 0,868 & 0,652 & 0,759 & 0,312 & 0,275 & 0,000 & 0,039 \\
\hline Indústria Têxtil & 0,733 & 1,006 & 2,507 & 2,233 & 1,003 & 1,141 & 2,216 & 1,862 & 0,772 & 0,436 & 0,550 & 0,387 \\
\hline Indústria Calçados & 0,166 & 0,037 & 0,867 & 0,598 & 0,490 & 0,351 & 0,067 & 0,090 & 0,111 & 0,000 & 0,107 & 0,076 \\
\hline Alimentos e Bebidas & 1,008 & 1,745 & 0,870 & 1,594 & 1,266 & 1,872 & 2,860 & 2,196 & 2,019 & 1,968 & 1,086 & 1,004 \\
\hline Serviço Utilidade Pública & 1,289 & 1,208 & 0,920 & 0,851 & 0,745 & 1,011 & 0,771 & 0,867 & 0,684 & 0,670 & 3,372 & 2,582 \\
\hline Construção Civil & 1,167 & 0,928 & 0,418 & 0,519 & 0,778 & 1,172 & 1,876 & 1,804 & 0,318 & 0,508 & 0,355 & 0,571 \\
\hline Comércio Varejista & 1,321 & 1,230 & 1,176 & 1,288 & 1,363 & 1,354 & 1,034 & 0,964 & 1,313 & 1,226 & 1,582 & 1,442 \\
\hline Comércio Atacadista & 2,514 & 1,730 & 1,053 & 1,234 & 1,240 & 1,371 & 1,016 & 1,135 & 2,818 & 2,214 & 1,322 & 1,085 \\
\hline Instituição Financeira & 1,605 & 1,366 & 0,791 & 1,470 & 1,246 & 1,318 & 1,080 & 1,191 & 2,084 & 1,623 & 1,249 & 1,603 \\
\hline Adm Técnica Profissional & 0,336 & 0,737 & 0,212 & 0,364 & 0,243 & 0,316 & 0,678 & 0,511 & 0,165 & 0,245 & 0,133 & 0,230 \\
\hline Transporte e Comunicações & 0,849 & 0,852 & 0,727 & 0,985 & 0,459 & 0,723 & 0,631 & 0,765 & 0,580 & 0,750 & 1,199 & 1,719 \\
\hline Aloj Comunic & 0,767 & 0,620 & 1,830 & 0,594 & 0,753 & 0,648 & 0,728 & 0,654 & 0,431 & 0,904 & 0,685 & 0,583 \\
\hline Médicos Odontológicos Vet & 1,024 & 0,912 & 0,730 & 0,826 & 0,765 & 0,652 & 0,869 & 0,789 & 1,757 & 1,166 & 1,047 & 0,832 \\
\hline Ensino & 1,127 & 0,991 & 0,489 & 0,502 & 1,098 & 0,764 & 0,982 & 0,901 & 0,078 & 0,104 & 0,515 & 0,318 \\
\hline Administração Pública & 0,862 & 0,845 & 1,049 & 1,333 & 1,767 & 1,584 & 0,738 & 0,877 & 1,574 & 1,684 & 1,597 & 1,551 \\
\hline Agricultura & 0,859 & 0,897 & 0,742 & 0,887 & 0,733 & 0,826 & 0,880 & 0,890 & 1,570 & 1,478 & 1,087 & 1,710 \\
\hline
\end{tabular}

Fonte: Resultados da pesquisa.

DRd - Desenvolvimento Regional em debate (ISSNe 2237-9029) 
A construção de usinas hidroelétricas, como a de Foz do Chapecó, na microrregião de Frederico Westphalen, ajuda a explicar a elevação do QL dos serviços industriais de utilidade pública. Com a inauguração da usina em 2010, pode-se sugerir que a usina pode ter influenciado no aumento do valor do QL em alguns ramos de atividade, mesmo que indiretamente, tais como: indústria química, têxtil, alimentos e bebidas, comércio e transporte. A microrregião de Erechim se destaca pela produção de máquinas, e não apenas para uso agrícola, mas máquinas para uso geral, o que contribui para as demais atividades industriais também terem QL acima da unidade, como as atividades de indústria metalúrgica, têxtil e alimentos.

Na microrregião de Sananduva, das atividades com QL maior do que a unidade em 2004, apenas duas tiveram aumento em 2014, são elas: produção mineral não-metálica e administração pública. Nas demais atividades, o QL maior do que a unidade reduziu, porém permanecendo acima de 1 .

Em Cerro Largo, quatro ramos de atividades se destacam: serviço de utilidade pública, instituição financeira, transporte e comunicações, e agricultura. Dentre estas atividades, serviços de utilidade pública foi o único ramo de atividade que reduziu o seu QL, contudo, tanto em 2004 quanto e 2014, o QL se mostrou muito acima da unidade.

A mesorregião Noroeste Rio-Grandense (B) é composta por sete microrregiões: Santo Ângelo, Ijuí, Carazinho, Passo Fundo, Cruz Alta, Não-Me-Toque e Soledade. O QL para estas microrregiões encontra-se na Tabela 3.

Os ramos de atividade que se destacam na microrregião de Santo Ângelo são ligados a comércio e serviços, além dos comércios varejista e atacadista, instituições financeiras, serviços médicos e de ensino que também apresentam QL acima de 1, indicando que o forte da economia dessa microrregião se concentra no setor terciário.

Já a microrregião de Ijuí apresenta uma distinção das demais. Possui QL acima de 1 no ramo de indústria mecânica, o que reflete a existência de fábricas de máquinas e equipamentos para agricultura. Entretanto, diferentemente da microrregião de Três Passos, Ijuí também possui QL acima de 1 nas atividades de agricultura. Isso sugere que parte da produção das máquinas é transacionada com agentes da própria microrregião.

A microrregião de Carazinho se destaca na parte têxtil, onde se localizam empresas do segmento de couro e peças de vestuário, apesar de seu QL ter caído em 2014, em relação a 2004 (GUERRERO E CONCEIÇÃO, 2011). O QL do comércio varejista possivelmente reflete a importância que o setor têxtil tem, produzindo e comercializando dentro da própria microrregião, ocorrendo efeito parecido com o que acontece nos ramos de produção de maquinas agrícolas e agricultura na microrregião de Ijuí.

Na microrregião de Passo Fundo, os valores observados de QL na área de produção de alimentos são explicados pela produção de derivados de cacau. A fabricação de produtos de metal pode ter influência nos QLs dos ramos de indústria metalúrgica e extração mineral (GUERRERO E CONCEIÇÃO, 2011). Em Cruz Alta, as atividades com maior QL são a agricultura, serviços e comércio, ou seja, a concentração maior dos empregos está nos setores primário e terciário. 
Tabela 3 - Quociente Locacional das microrregiões pertencentes à mesorregião Noroeste Rio-Grandense (B).

\begin{tabular}{|c|c|c|c|c|c|c|c|c|c|c|c|c|c|c|}
\hline $\begin{array}{c}\text { Microrregião/ } \\
\text { Ramo de atividade }\end{array}$ & & & & & Cara & zinho & Passo & Fundo & Cruz & Alta & & & Sole & dade \\
\hline & 2004 & 2014 & 2004 & 2014 & 2004 & 2014 & 2004 & 2014 & 2004 & 2014 & 2004 & 2014 & 2004 & 2014 \\
\hline $\begin{array}{l}\text { Extrativa Mineral } \\
\text { Prod. Mineral Não }\end{array}$ & 0,522 & 0,128 & 0,975 & 0,629 & 0,874 & 0,491 & 2,559 & 1,523 & 1,868 & 0,628 & 0,830 & 0,324 & 2,677 & 2,617 \\
\hline Metál & 0,855 & 0,654 & 0,734 & 0,850 & 0,774 & 0,742 & 0,752 & 1,211 & 0,534 & 0,540 & 1,799 & 2,305 & 3,370 & 2,430 \\
\hline Indústria Metalúrgica & 1,008 & 1,051 & 3,488 & 0,424 & 0,433 & 0,499 & 0,876 & 1,071 & 0,278 & 0,355 & 0,241 & $\begin{array}{l}0,361 \\
12,63\end{array}$ & 0,465 & 0,460 \\
\hline Indústria Mecânica & 0,051 & 0,038 & 3,698 & 5,942 & 1,381 & 1,101 & 1,973 & 1,413 & 1,330 & 1,824 & 7,007 & 6 & 0,013 & 0,061 \\
\hline Elétrico e Comunic & 0,051 & 0,180 & 3,970 & 4,117 & 0,018 & 0,181 & 0,357 & 0,261 & 0,029 & 0,021 & 0,018 & 0,110 & 0,000 & 0,000 \\
\hline Material de Transporte & 0,133 & 0,296 & 0,023 & 0,050 & 0,120 & 0,140 & 0,161 & 0,078 & 0,041 & 0,015 & 0,000 & 0,008 & 0,510 & 0,006 \\
\hline Madeira e Mobiliário & 0,714 & 0,389 & 0,333 & 0,337 & 0,785 & 1,124 & 0,733 & 0,590 & 0,505 & 0,299 & 0,430 & 0,377 & 1,199 & 0,671 \\
\hline $\begin{array}{c}\text { Papel e Gráf } \\
\text { Borracha, Fumo, }\end{array}$ & 0,742 & 0,713 & 0,322 & 0,366 & 0,703 & 0,696 & 0,481 & 0,709 & 0,595 & 0,541 & 1,392 & 1,171 & 0,101 & 0,162 \\
\hline & 0,726 & 0,121 & 0,170 & 0,501 & 0,161 & 0,230 & 0,763 & 0,591 & 0,124 & 0,232 & 5,487 & 0,046 & 3,276 & 2,504 \\
\hline Indústria Química & 0,169 & 0,253 & 0,183 & 0,392 & 0,506 & 0,723 & 0,432 & 0,793 & 0,353 & 0,442 & 0,089 & 0,066 & 0,139 & 0,321 \\
\hline Indústria Têxtil & 0,252 & 0,334 & 0,494 & 0,413 & 2,205 & 1,918 & 1,028 & 0,931 & 0,370 & 0,416 & 0,398 & 0,379 & 0,647 & 1,698 \\
\hline Indústria Calçados & 0,001 & 0,002 & 0,004 & 0,011 & 0,729 & 0,855 & 0,151 & 0,097 & 0,336 & 0,005 & 0,004 & 0,002 & 1,247 & 0,376 \\
\hline $\begin{array}{l}\text { Alimentos e Bebidas } \\
\text { Serviço Utilidade }\end{array}$ & 1,346 & 1,774 & 0,577 & 0,822 & 1,157 & 1,213 & 2,948 & 2,267 & 0,155 & 0,578 & 0,210 & 0,404 & 0,356 & 0,342 \\
\hline Pública & 0,793 & 0,862 & 0,826 & 0,984 & 1,407 & 1,280 & 0,679 & 0,681 & 2,564 & 1,791 & 0,342 & 0,405 & 2,375 & 2,437 \\
\hline Construção Civil & 0,822 & 0,765 & 0,738 & 0,781 & 1,232 & 1,055 & 0,764 & 0,995 & 0,511 & 0,559 & 0,707 & 0,674 & 0,792 & 0,648 \\
\hline Comércio Varejista & 1,584 & 1,414 & 1,307 & 1,256 & 1,352 & 1,245 & 1,299 & 1,201 & 1,541 & 1,386 & 0,903 & 0,905 & 1,264 & 1,353 \\
\hline Comércio Atacadista & 1,762 & 1,781 & 2,204 & 1,548 & 1,267 & 2,073 & 1,804 & 1,440 & 2,726 & 2,596 & 4,593 & 3,078 & 1,404 & 1,271 \\
\hline $\begin{array}{l}\text { Instituiç̃ão Financeira } \\
\text { Adm Técnica }\end{array}$ & 1,284 & 1,215 & 1,030 & 1,077 & 1,082 & 1,285 & 1,084 & 1,062 & 1,252 & 1,154 & 1,149 & 1,071 & 1,334 & 1,489 \\
\hline $\begin{array}{l}\text { Profissional } \\
\text { Transporte e }\end{array}$ & 0,341 & 0,469 & 0,444 & 0,493 & 0,296 & 0,482 & 0,619 & 0,798 & 0,326 & 0,573 & 0,216 & 0,189 & 0,365 & 0,314 \\
\hline Comunicações & 0,550 & 0,617 & 0,611 & 0,664 & 1,101 & 1,417 & 0,944 & 0,991 & 0,493 & 0,718 & 0,319 & 0,374 & 0,458 & 0,736 \\
\hline $\begin{array}{c}\text { Aloj Comunic } \\
\text { Médicos Odontológicos }\end{array}$ & 0,954 & 0,993 & 0,787 & 0,689 & 0,998 & 0,608 & 0,867 & 0,910 & 0,632 & 0,598 & 0,552 & 0,533 & 0,701 & 0,706 \\
\hline Vet & 1,097 & 1,126 & 1,053 & 1,280 & 0,914 & 0,709 & 1,663 & 1,523 & 1,146 & 1,017 & 0,565 & 0,318 & 0,944 & 1,209 \\
\hline Ensino & 1,388 & 0,936 & 1,780 & 0,949 & 0,719 & 0,565 & 1,581 & 1,253 & 1,549 & 0,764 & 0,223 & 0,268 & 0,174 & 0,232 \\
\hline Administração Pública & 1,160 & 1,183 & 0,837 & 0,915 & 0,851 & 1,030 & 0,546 & 0,610 & 1,202 & 1,224 & 0,826 & 0,904 & 1,396 & 1,872 \\
\hline Agricultura & 2,518 & 2,415 & 1,673 & 1,198 & 2,997 & 1,881 & 1,045 & 0,959 & 3,416 & 3,670 & 2,467 & 2,035 & 1,208 & 1,086 \\
\hline
\end{tabular}

Fonte: Resultados da pesquisa.

A microrregião Não-Me-Toque possui uma particularidade não observada em quaisquer outras microrregiões, que foi um QL de aproximadamente 12. A indústria mecânica teve seu QL de 7 em 2004, passando para 12,6 em 2014. Como já mencionado anteriormente em outra situação, o valor de QL muito acima da unidade não necessariamente representa um grande aumento da concentração de empregos neste setor nesta microrregião. Pode ser que o emprego nas demais microrregiões para esta atividade tenha reduzido. Outra particularidade encontra-se na atividade borracha, fumo e couros que reduziu drasticamente seu QL, de $5 \mathrm{em}$ 2004 para 0 em 2014.

Em Soledade, quatro são as atividades com maior concentração de empregos que merecem destaque: extrativa mineral; produção mineral não-metálica; borracha, fumo e couros; e serviço de utilidade pública.

Para a mesorregião Nordeste Rio-Grandense, composta pelas microrregiões Guaporé, Vacaria e Caxias do Sul, a Tabela 4 mostra os valores do QL relativos às respectivas microrregiões. 
Tabela 4 - Quociente Locacional das microrregiões pertencentes à mesorregião Nordeste Rio-Grandense.

\begin{tabular}{|c|c|c|c|c|c|c|}
\hline \multirow[t]{2}{*}{$\begin{array}{c}\text { Microrregião/ } \\
\text { Ramo de atividade }\end{array}$} & \multicolumn{2}{|c|}{ Guaporé } & \multicolumn{2}{|c|}{ Vacaria } & \multicolumn{2}{|c|}{ Caxias Do Sul } \\
\hline & 2004 & 2014 & 2004 & 2014 & 2004 & 2014 \\
\hline Extrativa Mineral & 11,624 & 5,833 & 0,301 & 0,586 & 0,503 & 0,723 \\
\hline Prod. Mineral Não Metálico & 2,636 & 3,300 & 0,795 & 1,138 & 1,011 & 1,291 \\
\hline Indústria Metalúrgica & 1,510 & 2,507 & 0,123 & 0,137 & 3,048 & 3,195 \\
\hline Indústria Mecânica & 0,988 & 0,882 & 0,626 & 0,445 & 1,725 & 1,778 \\
\hline Elétrico e Comunic & 0,355 & 0,353 & 0,119 & 0,143 & 3,167 & 2,418 \\
\hline Material de Transporte & 0,103 & 0,149 & 0,870 & 0,521 & 5,884 & 4,667 \\
\hline Madeira e Mobiliário & 3,144 & 2,017 & 4,522 & 4,110 & 3,762 & 3,125 \\
\hline Papel e Gráf & 0,804 & 2,682 & 1,072 & 0,693 & 1,451 & 1,517 \\
\hline Borracha, Fumo, Couros & 6,030 & 5,821 & 0,097 & 0,094 & 0,683 & 0,789 \\
\hline Indústria Química & 0,942 & 1,467 & 0,200 & 0,301 & 1,913 & 2,415 \\
\hline Indústria Têxtil & 2,241 & 3,535 & 0,644 & 0,547 & 2,654 & 2,295 \\
\hline Indústria Calçados & 1,188 & 0,382 & 0,492 & 0,526 & 0,394 & 0,366 \\
\hline Alimentos e Bebidas & 2,833 & 2,498 & 0,455 & 0,685 & 1,253 & 1,296 \\
\hline Serviço Utilidade Pública & 0,234 & 0,402 & 0,310 & 0,675 & 0,203 & 0,915 \\
\hline Construção Civil & 1,027 & 2,003 & 2,086 & 0,523 & 0,778 & 0,819 \\
\hline Comércio Varejista & 0,697 & 0,711 & 0,963 & 1,054 & 0,779 & 0,738 \\
\hline Comércio Atacadista & 0,263 & 0,732 & 0,679 & 0,960 & 0,860 & 0,946 \\
\hline Instituição Financeira & 0,578 & 0,743 & 0,582 & 0,750 & 0,760 & 0,859 \\
\hline Adm Técnica Profissional & 0,229 & 0,341 & 0,280 & 0,268 & 0,735 & 0,719 \\
\hline Transporte e Comunicações & 0,469 & 0,847 & 1,144 & 0,697 & 0,982 & 1,039 \\
\hline Aloj Comunic & 0,557 & 0,399 & 0,474 & 0,661 & 0,869 & 0,730 \\
\hline Médicos Odontológicos Vet & 0,527 & 0,456 & 0,587 & 0,568 & 0,875 & 0,799 \\
\hline Ensino & 0,278 & 0,246 & 0,269 & 0,269 & 0,910 & 1,040 \\
\hline Administração Pública & 0,616 & 0,743 & 0,569 & 0,917 & 0,306 & 0,318 \\
\hline Agricultura & 0,698 & 0,748 & 8,391 & 10,213 & 0,457 & 0,385 \\
\hline
\end{tabular}

Fonte: Resultados da pesquisa.

A microrregião de Guaporé possui empresas do segmento vestuário e roupas íntimas, explicando assim seu QL alto no ramo de indústria têxtil, e empresas na área de gemas e jóias, explicado pelo QL alto nos segmentos de extrativa mineral e produção mineral não metálica.

Já a microrregião de Vacaria possui um perfil diferente de distribuição do emprego formal. Em Vacaria, há uma aglomeração na área de madeira/moveleiro. Para Guerrero e Conceição (2011), aglomeração são núcleos de desenvolvimento regional-setorial, o que faz com que Vacaria concentre empregos formais nesse ramo de atividade, consequentemente, se especialize nesse segmento. Com base nos valores da Tabela 4, o QL sugere que as atividades relacionadas à madeira e agricultura formam a base econômica da microrregião.

A pesquisa de Guerrero de Conceição (2011) ressalta que a microrregião de Caxias do Sul possui especialização em alguns ramos de atividade que possuem importância setorial, mas não regional, talvez pelo fato de não possuírem encadeamentos para trás e para frente. São eles: Bebidas, têxtil, madeira e borracha. Fato confirmado pelo QL encontrado em 2014 para esta microrregião.

As microrregiões da mesorregião Metropolitana de Porto Alegre, (Montenegro, Gramado-Canela, São Jerônimo, Porto Alegre, Osório e Camaquã) têm o QL apresentado na Tabela 5. 
Tabela 5 - Quociente Locacional das microrregiões pertencentes à mesorregião Metropolitana de Porto Alegre.

\begin{tabular}{|c|c|c|c|c|c|c|c|c|c|c|c|c|}
\hline \multirow[t]{2}{*}{$\begin{array}{c}\text { Microrregião/ } \\
\text { Ramo de atividade }\end{array}$} & \multicolumn{2}{|c|}{ Montenegro } & \multicolumn{2}{|c|}{$\begin{array}{l}\text { Gramado- } \\
\text { Canela }\end{array}$} & \multicolumn{2}{|c|}{ São Jerônimo } & \multicolumn{2}{|c|}{ Porto Alegre } & \multicolumn{2}{|c|}{ Osório } & \multicolumn{2}{|c|}{ Camaquã } \\
\hline & 2004 & 2014 & 2004 & 2014 & $\begin{array}{l}\mathbf{2 0 0 4} \\
10,00\end{array}$ & 2014 & 2004 & 2014 & 2004 & 2014 & 2004 & 2014 \\
\hline $\begin{array}{l}\text { Extrativa Mineral } \\
\text { Prod. Mineral Não }\end{array}$ & 0,685 & 1,417 & 0,538 & 0,923 & 4 & 6,777 & 0,298 & 0,343 & 1,188 & 1,649 & 0,198 & 0,120 \\
\hline Metálico & 3,760 & 4,934 & 0,322 & 0,661 & 0,784 & 1,243 & 0,731 & 0,544 & 0,581 & 1,169 & 0,548 & 0,431 \\
\hline Indústria Metalúrgica & 0,593 & 1,309 & 0,642 & 0,784 & 2,928 & 2,661 & 0,902 & 0,788 & 0,110 & 0,159 & 0,632 & 0,445 \\
\hline Indústria Mecânica & 0,557 & 1,133 & 0,104 & 0,172 & 0,552 & 1,689 & 0,883 & 0,768 & 0,612 & 0,512 & 0,387 & 0,343 \\
\hline Elétrico e Comunic & 0,237 & 0,556 & 0,037 & 0,108 & 0,007 & 0,167 & 1,233 & 1,350 & 0,000 & 0,082 & 0,032 & 0,008 \\
\hline Material de Transporte & 0,207 & 0,285 & 0,017 & 0,018 & 0,950 & 1,011 & 0,698 & 0,646 & 0,120 & 0,279 & 0,111 & 0,027 \\
\hline Madeira e Mobiliário & 1,553 & 3,113 & 2,933 & 3,181 & 0,223 & 0,603 & 0,279 & 0,352 & 1,360 & 1,027 & 0,923 & 1,633 \\
\hline Papel e Gráf & 0,320 & 0,545 & 1,091 & 1,172 & 0,114 & 0,109 & 1,259 & 1,195 & 0,180 & 0,219 & 0,200 & 0,205 \\
\hline Borracha, Fumo, Couros & 3,388 & 3,902 & 2,161 & 2,110 & 0,253 & 0,116 & 0,820 & 0,926 & 0,073 & 0,043 & 0,381 & 0,448 \\
\hline Indústria Química & 2,477 & 3,124 & 1,084 & 0,708 & 5,842 & 5,560 & 1,097 & 0,914 & 0,178 & 0,138 & 0,296 & 0,219 \\
\hline Indústria Têxtil & 0,968 & 1,905 & 1,525 & 1,697 & 1,217 & 0,834 & 0,765 & 0,719 & 0,400 & 0,325 & 0,210 & 0,202 \\
\hline Indústria Calçados & 3,381 & 1,684 & 6,190 & 8,481 & 0,019 & 0,064 & 0,893 & 0,945 & 1,555 & 1,648 & 0,682 & 0,358 \\
\hline $\begin{array}{l}\text { Alimentos e Bebidas } \\
\text { Serviço Utilidade }\end{array}$ & 2,344 & 2,398 & 0,575 & 0,963 & 0,291 & 0,535 & 0,440 & 0,395 & 0,571 & 0,465 & 2,249 & 1,533 \\
\hline Pública & 0,259 & 0,360 & 0,280 & 0,293 & 1,855 & 1,576 & 1,113 & 1,065 & 1,183 & 1,064 & 0,825 & 0,849 \\
\hline Construção Civil & 1,055 & 0,935 & 0,526 & 0,715 & 0,680 & 0,589 & 1,157 & 1,115 & 1,223 & 1,158 & 0,525 & 1,762 \\
\hline Comércio Varejista & 0,756 & 0,842 & 0,664 & 0,851 & 0,849 & 0,904 & 0,845 & 0,835 & 1,721 & 1,708 & 1,408 & 1,403 \\
\hline Comércio Atacadista & 0,795 & 0,622 & 0,775 & 0,566 & 0,417 & 0,391 & 0,926 & 1,002 & 0,971 & 0,656 & 0,543 & 0,799 \\
\hline $\begin{array}{l}\text { Instituição Financeira } \\
\text { Adm Técnica }\end{array}$ & 0,336 & 0,588 & 0,489 & 0,623 & 0,503 & 0,629 & 1,177 & 1,105 & 0,638 & 0,543 & 0,710 & 0,727 \\
\hline $\begin{array}{l}\text { Profissional } \\
\text { Transporte e }\end{array}$ & 0,440 & 0,525 & 0,466 & 0,419 & 1,821 & 0,585 & 1,477 & 1,545 & 0,746 & 0,924 & 0,421 & 0,611 \\
\hline Comunicações & 0,505 & 0,809 & 0,432 & 0,633 & 1,386 & 1,620 & 1,182 & 1,081 & 0,660 & 0,634 & 0,577 & 0,680 \\
\hline $\begin{array}{l}\text { Aloj Comunic } \\
\text { Médicos Odontológicos }\end{array}$ & 0,610 & 0,590 & 0,850 & 1,234 & 0,486 & 0,704 & 1,165 & 1,204 & 1,008 & 1,082 & 0,725 & 0,585 \\
\hline Vet & 0,614 & 0,383 & 0,318 & 0,450 & 0,615 & 0,546 & 1,113 & 1,169 & 0,599 & 0,726 & 0,796 & 0,613 \\
\hline Ensino & 0,230 & 0,304 & 0,496 & 0,506 & 0,594 & 0,432 & 1,118 & 1,037 & 0,681 & 0,502 & 0,574 & 0,438 \\
\hline Administração Pública & 0,482 & 0,678 & 0,398 & 0,535 & 1,195 & 1,352 & 1,283 & 1,241 & 1,143 & 1,235 & 1,188 & 1,300 \\
\hline Agricultura & 0,748 & 1,201 & 0,219 & 0,292 & 0,964 & 1,213 & 0,094 & 0,100 & 1,295 & 1,155 & 3,937 & 3,631 \\
\hline
\end{tabular}

Fonte: Resultados da pesquisa.

As atividades relacionadas a minérios possuem relevância na microrregião de Montenegro, como indica o QL dos ramos de atividade de extração mineral e produção de mineral não metálicos, além de possuir fabricação de produtos químicos orgânicos, corroborando o alto QL da indústria química.

A microrregião de Gramado-Canela, assim como várias outras, possui QL significativo em atividades relacionadas à madeira e mobiliário. A indústria de papel de gráfica também é relevante na microrregião. Tem-se aí um encadeamento importante, sendo que uma das matérias-primas do papel é a madeira. Portanto, a indústria de papel e gráfica exerce um fator importante no encadeamento a montante.

Uma característica que se ressalta na microrregião de São Jerônimo é o QL relevante da Administração Pública. Regiões que possuem QL alto na Administração Pública geralmente possuem poucas atividades que são consolidadas na região, fato que não gera capacidade para os setores privados criarem mais empregos formais que o setor público. $\mathrm{O}$ 
efeito é que parte do emprego formal se localize no serviço público. O QL alto dos serviços de utilidade pública corrobora essa observação. A microrregião ainda possui setores com QL elevado, que tendem a ser intensivos em mão-de-obra, como agricultura, indústria têxtil e extrativa mineral.

A microrregião de Porto Alegre, por conter a capital do estado, tem especialização em alguns ramos de atividade mais complexos, seja por possuir instituições que há em toda capital, seja por possuir infraestrutura que garanta o funcionamento dessas atividades. São exemplos o setor elétrico, serviços de utilidade pública e, como é de se esperar em regiões em estágio mais avançado de desenvolvimento, um setor terciário mais consolidado, representado pelas atividades de construção civil, instituições financeiras, atividades relacionadas à saúde e ensino.

A microrregião de Osório possui uma dinâmica econômica mais voltada às atividades primárias, conforme os QLs da extração mineral, produção de minerais não metálicos $(\mathrm{QL}$ relevante em 2014) e agricultura. Essa base econômica se reflete em alguns QLs superiores a unidade em algumas atividades urbanas, especialmente às ligadas à construção civil, administração pública e comércio varejista. Já a microrregião de Camaquã possui dois QLs significativos em dois setores que são característicos de regiões de pouca expressão econômica: agricultura e administração pública, como já explicitado para a microrregião de São Jerônimo.

Na mesorregião Centro Oriental Rio-Grandense, o QL das microrregiões Santa Cruz do Sul, Lajeado-Estrela e Cachoeira do Sul encontra-se na Tabela 6.

Ao se analisar a microrregião de Santa Cruz do Sul, não há como deixar de registrar sua produção de fumo, como se pode observar pelo seu valor de QL. Ainda que a produção de fumo não seja muito bem vista por alguns grupos, essa é a segunda atividade que mais gerou emprego formal na microrregião de Santa Cruz do Sul em 2014. Acabar com essa atividade significa não só eliminar esses empregos, mas todo o encadeamento que existe por causa da atividade fumageira, até mesmo refletir negativamente no comércio, que é a atividade que mais emprega em Santa Cruz do Sul, o que é corroborado pelo QL acima da unidade, tanto do comércio varejista quanto do atacadista.

Tabela 6 - Quociente Locacional das microrregiões pertencentes à mesorregião Centro Oriental Rio-Grandense.

\begin{tabular}{ccccccc}
\hline $\begin{array}{c}\text { Microrregião/ } \\
\text { Ramo de atividade }\end{array}$ & \multicolumn{2}{c}{ Santa Cruz Do Sul } & \multicolumn{2}{c}{ Lajeado-Estrela } & \multicolumn{2}{c}{ Cachoeira Do Sul } \\
\hline & $\mathbf{2 0 0 4}$ & $\mathbf{2 0 1 4}$ & $\mathbf{2 0 0 4}$ & $\mathbf{2 0 1 4}$ & $\mathbf{2 0 0 4}$ & $\mathbf{2 0 1 4}$ \\
Extrativa Mineral & 0,401 & 0,467 & 1,181 & 2,714 & 6,647 & 5,306 \\
Prod. Mineral Não Metálico & 1,221 & 0,942 & 2,124 & 1,778 & 3,276 & 2,818 \\
Indústria Metalúrgica & 1,218 & 1,627 & 0,573 & 0,912 & 0,601 & 0,944 \\
Indústria Mecânica & 1,201 & 1,427 & 0,280 & 0,468 & 1,769 & 1,393 \\
Elétrico e Comunic & 0,692 & 1,331 & 0,163 & 0,233 & 0,805 & 0,398 \\
Material de Transporte & 0,144 & 0,249 & 0,111 & 0,344 & 0,150 & 0,139 \\
Madeira e Mobiliário & 0,538 & 0,914 & 1,188 & 1,465 & 0,819 & 0,546 \\
Papel e Gráf & 0,645 & 0,773 & 0,901 & 0,912 & 1,024 & 0,974 \\
Borracha, Fumo, Couros & 4,919 & 4,737 & 1,672 & 1,460 & 0,584 & 0,557 \\
Indústria Química & 0,942 & 0,965 & 1,168 & 1,050 & 0,128 & 0,122 \\
Indústria Têxtil & 1,619 & 2,060 & 0,921 & 1,259 & 0,202 & 0,244 \\
Indústria Calçados & 1,084 & 1,083 & 3,465 & 2,981 & 0,144 & 0,505 \\
\hline
\end{tabular}

DRd - Desenvolvimento Regional em debate (ISSNe 2237-9029)

v. 7, n. 1, p. 144-163, maio 2017. 


\begin{tabular}{ccccccc} 
Alimentos e Bebidas & 0,834 & 0,913 & 3,073 & 3,468 & 1,332 & 1,521 \\
Serviço Utilidade Pública & 0,838 & 0,358 & 0,454 & 0,531 & 1,663 & 1,391 \\
Construção Civil & 0,990 & 0,836 & 0,983 & 1,168 & 0,400 & 0,419 \\
Comércio Varejista & 1,176 & 1,202 & 0,922 & 0,943 & 1,431 & 1,283 \\
Comércio Atacadista & 1,098 & 1,079 & 0,646 & 0,655 & 0,996 & 1,619 \\
Instituição Financeira & 0,866 & 0,976 & 0,749 & 0,851 & 0,947 & 1,064 \\
Adm Técnica Profissional & 0,801 & 0,636 & 0,419 & 0,557 & 0,268 & 0,289 \\
Transporte e Comunicações & 0,849 & 1,014 & 0,854 & 1,077 & 0,856 & 0,734 \\
Aloj Comunic & 1,022 & 1,008 & 0,608 & 0,687 & 0,785 & 0,797 \\
Médicos Odontológicos Vet & 0,946 & 0,882 & 0,581 & 0,642 & 1,284 & 1,004 \\
Ensino & 1,214 & 1,169 & 0,622 & 0,676 & 1,135 & 0,699 \\
Administração Pública & 0,615 & 0,629 & 0,470 & 0,591 & 0,910 & 1,139 \\
Agricultura & 0,460 & 0,480 & 0,585 & 0,650 & 3,437 & 3,029 \\
\hline
\end{tabular}

Fonte: Resultados da pesquisa.

A microrregião de Lajeado-Estrela possui empresas no segmento de laticínios, o que explica o QL alto no ramo de alimentos e bebidas. Outros ramos de atividade que se destacam na microrregião são indústria de calçados, extração mineral e produção de minerais não metálicos. A microrregião de Cachoeira do Sul possui uma dinâmica econômica parecida com a de Osório (mesorregião Metropolitana de Porto Alegre), apresentando QLs significativos em atividades pertencentes ao setor primário, como agricultura, extração mineral e produção de minerais não metálicos.

Quanto à mesorregião Centro Ocidental Rio-Grandense, esta é composta pelas microrregiões de Santiago, Santa Maria e Restinga Seca. O QL para os ramos de atividades destas microrregiões está exposto na Tabela 7.

Tabela 7 - Quociente Locacional das microrregiões pertencentes à mesorregião Centro Ocidental RioGrandense.

\begin{tabular}{ccccccc}
\hline Microrregião/ & \multicolumn{2}{c}{ Santiago } & \multicolumn{2}{c}{ Santa Maria } & Restinga Seca \\
Ramo de atividade & $\mathbf{2 0 0 4}$ & $\mathbf{2 0 1 4}$ & $\mathbf{2 0 0 4}$ & $\mathbf{2 0 1 4}$ & $\mathbf{2 0 0 4}$ & $\mathbf{2 0 1 4}$ \\
& 0,621 & 0,501 & 1,701 & 1,084 & 2,265 & 1,234 \\
Extrativa Mineral & 1,034 & 1,184 & 1,457 & 0,936 & 3,245 & 3,475 \\
Prod. Mineral Não Metálico & 0,121 & 0,235 & 0,354 & 0,431 & 0,302 & 0,288 \\
Indústria Metalúrgica & 0,066 & 0,128 & 0,254 & 0,414 & 0,107 & 0,100 \\
Indústria Mecânica & 0,000 & 0,000 & 0,226 & 0,339 & 0,069 & 0,206 \\
Elétrico e Comunic & 0,031 & 0,035 & 0,169 & 0,118 & 0,000 & 0,000 \\
Material de Transporte & 0,544 & 0,552 & 0,252 & 0,266 & 3,689 & 2,754 \\
Madeira e Mobiliário & 0,255 & 0,343 & 0,758 & 0,715 & 0,195 & 0,562 \\
Papel e Gráf & 1,418 & 0,142 & 1,239 & 0,620 & 0,046 & 0,151 \\
Borracha, Fumo, Couros & 0,051 & 0,074 & 0,201 & 0,280 & 0,060 & 0,018 \\
Indústria Química & 0,213 & 0,538 & 0,365 & 0,297 & 0,340 & 0,599 \\
Indústria Têxtil & 0,002 & 0,019 & 0,029 & 0,190 & 1,373 & 1,681 \\
Indústria Calçados & 1,456 & 0,686 & 0,867 & 0,913 & 1,642 & 1,589 \\
Alimentos e Bebidas & 0,831 & 0,602 & 3,749 & 0,889 & 1,994 & 1,769 \\
Serviço Utilidade Pública & 0,571 & 0,903 & 1,393 & 0,938 & 0,491 & 0,705 \\
Construção Civil & 1,438 & 1,437 & 1,460 & 1,333 & 1,141 & 1,323 \\
Comércio Varejista & 1,709 & 1,621 & 0,915 & 0,782 & 1,355 & 1,033 \\
Comércio Atacadista & 1,092 & 1,169 & 1,352 & 1,112 & 1,822 & 1,192 \\
Instituição Financeira & 0,252 & 0,468 & 0,671 & 0,716 & 0,173 & 0,333 \\
Adm Técnica Profissional & & & & & & \\
\hline
\end{tabular}

DRd - Desenvolvimento Regional em debate (ISSNe 2237-9029) 


\begin{tabular}{ccccccc} 
Transporte e Comunicações & 0,331 & 0,434 & 0,929 & 1,031 & 0,364 & 0,605 \\
Aloj Comunic & 0,573 & 0,629 & 1,199 & 1,635 & 0,841 & 0,570 \\
Médicos Odontológicos Vet & 0,979 & 1,008 & 1,196 & 1,187 & 0,637 & 0,990 \\
Ensino & 1,184 & 0,854 & 1,327 & 3,008 & 0,235 & 0,183 \\
Administração Pública & 1,305 & 1,445 & 1,163 & 0,729 & 1,305 & 1,519 \\
Agricultura & 4,873 & 5,358 & 1,260 & 1,079 & 1,873 & 1,460 \\
\hline
\end{tabular}

Fonte: Resultados da pesquisa.

À primeira vista, o QL que se destaca na microrregião de Santiago é o da agricultura, que já era substancial em 2004 e se tornou maior ainda em 2014. Combinando o QL da agricultura com os demais ramos de atividade com QL superior a unidade, tem-se a hipótese de que a agricultura possui um efeito positivo sobre as demais atividades urbanas, em especial às do setor terciário, como instituições financeiras, comércio atacadista e varejista. Contudo, há a retração substancial do QL no segmento de borracha, fumos e couro.

Na microrregião de Santa Maria, as atividades de ensino se destacam mais do que as demais atividades quando observado o QL de 2014. Por outro lado, as atividades de serviços de utilidade pública perderam fortemente a concentração de emprego, passando de um QL acima de 3, em 2004, para um abaixo de 1, em 2014.

Em Restinga Seca, atividades relacionadas à indústria extrativa mineral, produção mineral não metálica e madeira e mobiliário são as que mais se destacam. Porém, assim como nas demais microrregiões, a agricultura também impulsiona o desenvolvimento das demais atividades.

A última mesorregião analisada, Sudoeste Rio-Grandense, é composta por três microrregiões, a saber: Campanha Ocidental, Campanha Central e Campanha Meridional. O QL destas microrregiões está apresentado na Tabela 8.

Tabela 8 - Quociente Locacional das microrregiões pertencentes à mesorregião Sudoeste Rio-Grandense.

\begin{tabular}{ccccccc}
\hline $\begin{array}{c}\text { Microrregião/ } \\
\text { Ramo de atividade }\end{array}$ & \multicolumn{2}{c}{ Campanha Ocidental } & \multicolumn{2}{c}{ Campanha Central } & \multicolumn{2}{c}{ Campanha Meridional } \\
\hline & $\mathbf{2 0 0 4}$ & $\mathbf{2 0 1 4}$ & $\mathbf{2 0 0 4}$ & $\mathbf{2 0 1 4}$ & $\mathbf{2 0 0 4}$ & $\mathbf{2 0 1 4}$ \\
Extrativa Mineral & 0,732 & 0,698 & 0,262 & 0,643 & 0,790 & 0,498 \\
Prod. Mineral Não Metálico & 0,251 & 0,166 & 0,071 & 0,307 & 0,366 & 0,404 \\
Indústria Metalúrgica & 0,107 & 0,149 & 0,070 & 0,131 & 0,135 & 0,090 \\
Indústria Mecânica & 0,068 & 0,101 & 0,126 & 0,098 & 0,006 & 0,049 \\
Elétrico e Comunic & 0,000 & 0,088 & 0,136 & 0,016 & 0,000 & 0,122 \\
Material de Transporte & 0,043 & 0,013 & 0,012 & 0,012 & 0,003 & 0,011 \\
Madeira e Mobiliário & 0,075 & 0,091 & 0,189 & 0,142 & 0,100 & 0,113 \\
Papel e Gráf & 0,245 & 0,199 & 0,465 & 0,494 & 0,286 & 0,343 \\
Borracha, Fumo, Couros & 0,062 & 0,115 & 0,085 & 0,054 & 0,169 & 0,223 \\
Indústria Química & 0,007 & 0,006 & 0,086 & 0,092 & 0,011 & 0,039 \\
Indústria Têxtil & 0,293 & 0,281 & 0,198 & 0,291 & 0,562 & 0,527 \\
Indústria Calçados & 0,005 & 0,014 & 0,003 & 0,006 & 0,003 & 0,006 \\
Alimentos e Bebidas & 1,297 & 1,182 & 0,883 & 1,333 & 2,169 & 2,131 \\
Serviço Utilidade Pública & 1,016 & 0,978 & 0,513 & 1,185 & 1,733 & 0,779 \\
Construção Civil & 0,452 & 0,792 & 0,720 & 0,426 & 0,420 & 0,616 \\
Comércio Varejista & 1,627 & 1,559 & 1,703 & 1,737 & 1,360 & 1,408 \\
Comércio Atacadista & 0,656 & 0,664 & 0,825 & 0,743 & 0,777 & 0,609 \\
Instituição Financeira & 0,854 & 0,778 & 0,822 & 0,852 & 0,870 & 0,805 \\
\hline
\end{tabular}

DRd - Desenvolvimento Regional em debate (ISSNe 2237-9029) 


\begin{tabular}{cllllll} 
Adm Técnica Profissional & 0,494 & 0,416 & 0,726 & 0,456 & 0,452 & 0,400 \\
Transporte e Comunicações & 1,221 & 1,118 & 0,518 & 0,684 & 0,515 & 0,601 \\
Aloj Comunic & 0,760 & 0,699 & 0,923 & 0,978 & 0,825 & 0,724 \\
Médicos Odontológicos Vet & 1,017 & 0,974 & 1,378 & 1,141 & 1,299 & 0,935 \\
Ensino & 0,877 & 0,524 & 1,050 & 0,741 & 1,692 & 2,148 \\
Administração Pública & 0,998 & 1,209 & 1,018 & 1,079 & 1,001 & 1,188 \\
Agricultura & 6,393 & 6,423 & 5,792 & 5,337 & 5,769 & 4,823 \\
\hline
\end{tabular}

Fonte: Resultados da pesquisa.

Nas três microrregiões, a agricultura foi a atividade que mais gerou emprego formal, sendo esta uma atividade base para a mesorregião. Fato corroborado pelo elevado valor do QL para ambos os anos em todas as microrregiões.

Na microrregião Campanha Ocidental, além da agricultura, as atividades relacionadas à indústria de alimentos e bebidas, serviço de transporte e telecomunicações e comércio varejista e administração pública são atividades que concentram o maior número de empregos.

A microrregião Campanha Central também possui atividades do comércio varejista como concentradora de emprego, juntamente com os serviços médicos veterinários e administração pública.

O comércio varejista também se destacou na Campanha Meridional, junto com as indústrias de alimentos e bebidas e administração pública. Nesta microrregião ressaltam-se também as atividades de ensino, como em Santa Cruz do Sul (mesorregião Centro Oriental) e em Santa Maria (mesorregião Centro Ocidental).

Após analisar a distribuição do emprego formal nas 35 microrregiões do Rio Grande do Sul, percebe-se que as atividades que fazem parte da base exportadora, em geral, pertencem aos setores secundários e terciários. A agricultura (setor primário) apresentou-se como atividade básica em poucas microrregiões. Contudo, North (1977) afirma que a agropecuária é uma atividade básica por natureza, independentemente do valor encontrado para o QL, devido sua geração de excedentes. Isto quer dizer que a agropecuária pode apresentar QL abaixo da unidade devido à modernização do campo, dispensando mão de obra, porém, não deixa de ser importante para que as demais atividades sejam realizadas, isto é, a agropecuária é também fornecedora de matéria-prima para as demais atividades econômicas.Além disso, assim como qualquer região que caminha para o desenvolvimento, as microrregiões do Rio Grande do Sul estão se especializando mais no setor secundário, porém, apresentando tendência de especialização para o setor terciário.

Os trabalhos de Lara et al. (2010), cuja análise baseia-se apenas em 2008; Piccinini et al. (2011), cuja análise foi feita para 2000 e 2009; e Scherer e Moraes (2012), cuja análise foi realizada para os anos 2000 e 2010; corroboram com os achados desta pesquisa. 


\section{CONSIDERAÇÕES FINAIS}

O objetivo dessa pesquisa foi analisar a distribuição do emprego formal nas microrregiões do estado do Rio Grande do Sul, comparando os anos 2004 e 2014. O estado é composto por 35 microrregiões, agregadas em sete mesorregiões.

Os resultados mostraram que a agricultura mostrou ser um ramo de atividade que impulsiona as demais atividades devido ao encadeamento para trás e para frente, atraindo e concentrando o emprego na maioria das microrregiões, corroborando com a assertiva de North $(1955 ;$ 1977). Além disso, os encadeamentos evidenciados corroboram a argumentação de Hirschman, ao frisar tanto os efeitos para trás do setor terciário para o secundário e primário, quando do setor secundário para o primário. $\mathrm{O}$ uso do referencial teórico dos encadeamentos de Hirschman se deve pela existência desses encadeamentos em algumas das microrregiões analisadas neste artigo. Estes encadeamentos aparecem em regiões onde a agricultura é atividade relevante, evidenciado pelo valor do quociente locacional, sendo que o quociente locacional sugere que atividades da área urbana também são relevantes. Os encadeamentos podem surgir quando atividades rurais são relevantes para a região, aliado a QL relevante em atividades ligadas ao comércio, por exemplo.

Na microrregião de Três Passos, tem-se um exemplo da teoria da base de exportação de Douglass North na medida em que a atividade de produção de máquinas é significativa, porém a atividade de agricultura não o é. Isso sugere que a produção de máquinas não é transacionada na própria região, mas sim exportada, não necessariamente para outros países, mas para outras regiões do Brasil ou do próprio Rio Grande do Sul.

A noção de pólos de desenvolvimento de Perroux tem algumas ligações com o QL, na medida em que alguns ramos de atividade podem auxiliar no desenvolvimento das regiões, seja agregando mais valor ou ajudando a consolidar a estrutura produtiva da região, incorporando mais tecnologia ou com aumento nas exportações, assim como a indústria de transformação.

Dessa forma, observa-se que algumas microrregiões estão em um processo de polarização, onde os municípios grandes estão determinando o padrão de especialização produtiva dos municípios menores.

\section{REFERÊNCIAS}

ATLAS SOCIOECONÔMICO DO RIO GRANDE DO SUL. Economia. Disponível em: $<$ http://www.atlassocioeconomico.rs.gov.br/conteudo.asp?cod_menu_filho=818\&cod_menu= 817\&tipo_menu=ECONOMIA\&cod_conteudo=1468>. Acesso em: 8 abr. 2016.

BACHA, C. J. C. Economia e política agrícola no Brasil. São Paulo: Atlas, 2004. 
EBERHARDT, P. Perfil do emprego formal nas microrregiões baianas: uma aplicação do quociente locacional e do multiplicador de emprego. Revista Mosaicum, v. 1, p. 113-136, 2014.

FURTADO, C. Introdução ao desenvolvimento: enfoque histórico estrutural. $3^{\circ} \mathrm{Ed}$. Rio de Janeiro: Editora Paz e Terra, 2000.

GUERRERO, G A.; CONCEIÇÃO, C. S. Identificação e classificação das aglomerações produtivas e dos Arranjos Produtivos Locais no Rio Grande do Sul. Texto de Discussão FEE, n. 92, 2011.

HADDAD, P.R. Economia Regional, teorias e métodos de análise. Fortaleza: BNB; Etene, 1989.

HIRSCHMAN, A. Estratégia do Desenvolvimento Econômico. Rio de Janeiro: Fundo de Cultura, 1961. Edição original de 1958.

IBGE - Instituto Brasileiro de Geografia e Estatística. Disponível em:

$<$ http://www.ibge.gov.br>. Acesso em 4 dez. 2016.

LARA, F. M.; FIORI, T. P.; ZANIN, V. Notas sobre medidas de concentração e especialização: um exercício preliminar para o emprego no Rio Grande do Sul. Texto para Discussão, n. 83, Porto Alegre: FEE, 2010.

LIMA, A. C. C.; SIMÕES, R. F. Teorias do desenvolvimento regional e suas implicações de política econômica no pós-guerra: o caso do Brasil. Texto para discussão, n. 358 . Belo Horizonte: UFMG/Cedeplar, 2009.

MONASTERIO, L. Indicadores de análise regional e espacial. In: CRUZ, B.; FURTADO, B.; MONASTÉRIO, L.; JÚNIOR. W. (Org.). Economia Regional e Urbana: teorias e métodos com ênfase no Brasil. Brasília: IPEA, p. 315-331, 2011.

MONASTÉRIO, L; CAVAlCANTE, L. Fundamentos do Pensamento Econômico Regional. In: CRUZ, B.; FURTADO, B.; MONASTÉRIO, L.; JÚNIOR. W. (Org.). Economia Regional e Urbana: teorias e métodos com ênfase no Brasil. Brasília: IPEA, 2011, p. 43-77.

MYRDAL, G. Teoria econômica e regiões sub-desenvolvidas. Rio de Janeiro: Saga, 1957.

NERU/FEE - NÚCLEO DE ESTUDOS REGIONAIS E URBANOS/FUNDAÇÃO DE ECONOMIA E ESTATÍSTICA. Mapas. Disponível em:

$<$ http://mapas.fee.tche.br/microrregioes-geograficas-ibge-rio-grande-do-sul-2009.html $>$. Acesso em: 31 mar. 2017.

NORTH, D. Location theory and regional economic growth. Journal of Political Economy, v. 63, 1955.

. Teoria da localização e crescimento econômico regional In: J. SCHWARTZMANN (org.). Economia regional e urbana: textos escolhidos. Belo Horizonte: UFMG, 1977, p. 333-343. 
PERROUX, F. O conceito de pólo de desenvolvimento. In: SCHWARTZMAN, J. (Org.). Economia regional: textos escolhidos. Belo Horizonte: CEDEPLAR, p.145-156, 1977.

PICCINI, F. Jr.; FINAMORE, E. B. M. C.; OLIVEIRA, G. Identificação e mapeamento de aglomerações produtivas no Rio Grande do Sul: um enfoque na região da produção.

Cadernos de Economia, v. 15, n. 28, jan./jun. 2011.

PIFFER, M. A dinâmica do Oeste paranaense: sua inserção na economia nacional. Dissertação de Mestrado (Programa de Pós-Graduação em Desenvolvimento Econômico Mestrado) - Universidade Federal do Paraná. Curitiba. 1997.

. Apontamentos sobre a base econômica da Região Oeste do Paraná. In: CASSIMIRO FILHO, F. \& SHIKIDA, P. F. A. (Org.). Agronegócio e Desenvolvimento Regional. Cascavel, PR: Edunioeste, p. 57-84, 1999.

RAIS - Relação Anual de Informações Sociais. Disponível em:

<http://www.mte.gov.br/geral/estatisticas.asp?viewarea=rais >. Acesso em 25 set. 2016.

SCHERER, W. J. G.; MORAES, S. L. Análise locacional das atividades dinâmicas do Estado do Rio Grande do Sul. In: ENCONTRO DE ECONOMIA GAÚCHA, Mesa 11, 6, 2012, Porto Alegre. Anais... Porto Alegre: FEE, maio/jun. 2012.

Artigo recebido em: 24/02/2017

Artigo aprovado em: 25/04/2017 